\title{
Azerbaycan Basınında 1915 Ermeni Meselesi
}

\author{
Armenian Issue in 1915 in Azerbaijan Press
}

\author{
Doç. Dr. Hasan Mert - Doç. Dr. Vefa Kurban
}

\section{Öz}

Ermeni meselesi denilince akla öncelikle 1915 yllinda gerçekleșen tehcir hadisesi ve devaminda yaşanan olaylar gelir. Bu konunun öncelikli muhataplarından birisi Osmanl Devleti dolayısıla devamında Türkiye Cumhuriyeti olduğu gibi diğer bir cephesi de Azerbaycan devletidir. Birinci Dünya Savaşının devam ettiği bir dönemde Osmanl idarecilerinin takip ettikleri Ermeni politikası hakkında bugüne kadar çeşitli yayınlar ve bunlara bağh olarak yorumlar yapılmıştı. Öte yandan Azerbaycanin konuyla alakası hakkında ise bilgilerimiz sinırliydı. Bu itibarla tarih araştırmalarında çok önemli bir yere sahip olan matbuatın da değerlendirilmesiyle incelenen konulara katkı sağlanacağı açıktır. Dönemin Azerbaycan basını da konuya ilgi göstermiş, gerek kendi elde ettiği bilgilerle gerekse diğer dünya basınından derlediği haberlerle kendi bakış açısını ortaya sermiştir. Bu çalışmada dolaylı olarak Ermeni kamuoyunun da 1915 olayları ve Ermeni meselesine karşı tutumu dönemin kaynaklarının verdiği bilgiler ışı̆̆ında ortaya konmuş olacaktır. Bu çerçevede Ermeni Propagandalarl,1915 Tehcir'i, Van Olaylarl, Ermenilerin diğer etnik topluluklarla ve devletlerle ilişkilerine temas edilecektir.

Anahtar Kelimeler: 1915, Ermeni, Azerbaycan, Matbuat

\begin{abstract}
The incident of relocation in 1915 and the following incidents are the first things that come to mind when the Armenian issue is mentioned. Besides the Ottoman Empire, one of the primary related parties of the issue, and the Turkish Republic, Azerbaijan is another related party of the Armenian issue. Till today, various publications and comments have been made on the policies followed by the magisters of the Ottoman Empire towards Armenian people during the World War I. However, we do have very limited information on the role of Azerbaijan in this issue. In this respect, it is clear that evaluation of the printed press, which has an important place in historical researches, will contribute to relevant investigations. Azerbaijani press of the period showed an interest in the matter and revealed their own perspective on the issue benefiting from both the inquiries they made and the news they collected from the world press. This study will indirectly present the attitudes of the Armenian public towards the 1915 incidents and the Armenian issue in the light of the information provided by the sources of the period. And also this study is about the Armenian propaganda, relocation in 1915, Van events, Armenians relations with other ethnic communities and states.
\end{abstract}

Keywords: 1915, Armenian, Azerbaijan, Press

Doç. Dr. Hasan Mert, Ege Üniversitesi, hasamert@gmail.com

Doç. Dr. Vefa Kurban, İzmir Ekonomi Üniversitesi, vefa.kurban@deu.edu.tr 


\section{Kaynaklara Dair}

Özellikle Azerbaycan matbuatında farklı bir yere sahip olan üç gazetenin 1915 yılına ait tüm nüshaları gözden geçirilmiş ve Ermeni meselesine dair verdikleri bilgiler değerlendirilmiştir. Bunlar "Basiret, Yeni İkbal ve Açık Söz” gazeteleridir. Bu gazetelerde "Ermeni Matbuatından” başlı̆̆ı ile bazı Ermeni gazetelerinde (Mşak, Horizon, Aref) yer alan haberlerin Türkçeleştirilerek verildiği tespit edilmiştir.

1915 yılında Azerbaycan'da yayınlanmış olan “Açık Söz" gazetesi "İkbal” gazetesinin devamı niteliğinde olup, "Müsavat" partisinin resmi yayın organıdır. Bakü’de Azerbaycan Türkçesinde 1915-1918 yılları arasında günlük olarak yayınlanmıştır. Siyasi, içtimai bir gazete niteliği taşımaktadır. Gazetenin ilk sayısı 2 Ağustos 1915, son sayısı ise 18 Mart 1918 tarihinde neşrolunmuştur. Gazetenin toplam 704 sayısı yayınlanmıştır. Gazete milliyetçi fikirleri savunmuştur. Proletarya beynelmilelciliğine karşı çıkmıştır. Naşirleri ve redaktörleri Mehmet Emin Resulzade, Mehmet Ali Resulzade, Orucov kardeşler ve diğerleri olmuştur (ACE, 1976, s. 503).

"Basiret” Bakü'de Azerbaycan Türkçesinde yayınlanan haftalık siyasi, içtimai, iktisadi ve edebi bir gazetedir. 1914-1920 yılları arasında yayınlanmıştır. Gazetenin ilk sayısı 12 Nisan 1914 tarihinde, son sayısı ise 15 Mayıs 1920 yılında yayınlanmıştır. Toplam 281 sayısı neşrolunmuştur. 1918 yılı Mart-Eylül arası gazete çıkmamıştır. "Basiret” Müsavat (Devrim karşıtı) döneminde milliyetçi bir yayın organı görünümündedir. Daha sonraları Azerbaycan'daki Sovyet hâkimiyetini onaylamış, hatta V.İ.Lenin'in Sovyet Azerbaycanlılarına göndermiş olduğu kutlamayı 08.05.1920 tarihli sayısında yayınlanmıştır. "Basiret" te Neriman Nerimanov, M. S. Ordubadi, M. C. Pişeveri, M. Hadi, A Sehhet ve diğerleri yazılar kaleme almışlardır. (ACE,1978, s.150).

"İkbal" gazetesinin devamı niteliğinde olan "Yeni İkbal” gazetesi 1915-1917 yılları arasında Bakü'de yayınlanmıştır. Gazete liberal-burjuva ideolojisine sahiptir. Bakü’de Orucov kardeşler tarafından toplam 662 sayı yayınlanmıştır. Gazetenin ilk sayısı 28 Nisan 1915, son sayısı ise 31 Aralık 1917 tarihinde yayınlanmıştır. Derginin redaktörleri Üzeyir Hacıbeyov, Oruc Orucov ve diğerleridir. "Açık Söz” gazetesi ile birleştirildikten sonra yayın hayatı sona ermiştir.(ACE,1981, s. 113).
Araştırmada elbette 1915 yılında Azerbaycan'da yayınlanan haberler referans alınmış olsa da bu haberlerin önemli bir kısmının "Ermeni Matbuatından" altbaşlığı ile alıntılanmış ve çevirisinin yapılmış olması, dolaylı olarak ele alınan konulara Ermeni bakış açısını da yansıtmaktadır. Bazı haberlerin altında haberin gerçekte hangi gazetede çıktığı ve Azerbaycan Türkçesine kimin tarafından çevrildiği açık bir şekilde belirtilmiştir.

\section{Giriş}

Osmanlı Devleti'nin gerileme döneminde Rumlar, Sırplar, Karadağlılar, Bulgarlar ve Romenler milliyetçilik akımının etkisi ile teşkilatlanmaya başladılar. 1829 yılında Türk-Rus savaşının sonunda Rumlar, Yunan devletini kurmaya muvaffak oldular. Ermeniler de bu Yunan örneğinin etkisi ile Anadolu topraklarında bir Ermeni devleti kurma hayaline kapıldılar. Hatta Horizon gazetesinde yer alan bir makalede (bu haberin Ermeniceden çevirisi Yeni İkbal gazetesinde yayınlanmıştır) “Gözümüzün önünde bizden büyük olmayan Sırp, Bulgar, Karadağlilar öz bütün maddi ve manevi kuvvelerini ya hürriyet kazanmak yahut tarih-i umumide lekedar iz birakmamaktan ötürü bezl ediyor ve hiçbir fedakârliktan geri durmuyorlar. Ermeni ise can vermeye adet edip yol vermeye yok. Isşte nakıs ve lekedar olmanıza sebep bu olmuştur (Yeni İkbal, 16 Ağustos 1915)" diyerek bu örneklere dikkat çekiyordu. Avrupa emperyalizminin Türk topraklarını parçalama ve paylaşma projesinde bir piyon olmaktan öte geçemeyen Ermeniler, Türk yönetiminde asırlarca barış içinde yaşadıkları topraklarda demografik olarak herhangi bir bölgede nüfus çoğunluğu sağlayamamış olmalarına rağmen bu kışkırtmanın peşinde sürüklenip gitmişlerdir. Yakın tarihte yaşanmış olaylara atıfta bulunan bir Ermeni yorumunda; Ermeniler Türkiye'nin İran ve Rus sinırlarında gönüllü birlikleri oluşturup, korunma sağlamak veya saldıranlardan intikam almaları amacıyla dağlarda derelerde gizlenip ara sıra Kürt yerleşimlerine hücum ve yağmayla onları tehdit etmeyle meşguldüler. Hatta Balkan savaşlarında bu gönüllüler ile Bulgarlara yardim bile ediliyordu. Ama "Namert Avrupa ancak hiffetle kenardan bakıp hır hır hırıldadı."(Yeni İkbal, 30 Eylül 1915) Yani Avrupalılar Ermenilere vaad ettiği yardımı hiçbir zaman yapmadı. 
Osmanlı idaresi altında yaşayan Ermeniler ilk defa 1829 Türk-Rus savaşının doğu cephesinde Ruslara kılavuzluk ederek devletlerine karşı ihanet çemberine dahil olmuşlardır. Bundan sonra tarihte 93 harbi olarak bilinen 1877-1878 Türk-Rus savaşında Rus ordusu Erzurum'u kuşattığı sırada birkaç bin Ermeni, halkın ve ordunun manevi gücünü kırmak, bozgun ve panik çıkarmak için harekete geçmişlerdi.(Arif, 405, s.536). Bu savaşta Osmanlı Devleti ağır yenilgiye uğramış, Rus ordusu Ayastefanos’a (Yeşilköy) kadar ilerleyebilmişti. Edirne'de barış görüşmeleri başlamıştı. İşte Ermeni meselesi bu görüşmeler sırasinda Ermeni Patriki Nerses'in idaresinde Edirne'deki Ermeni papazlarının, Rus ordusu başkomutanını görmeleri sonunda ortaya çıktı. Emperyalistler, Ermeni meselesini sslahat yutturmacasiyla Ayastefanos Andlaşması'na on altıncı madde olarak koydurmayı başardılar.(Armaoğlu, 1999, s. 522) ${ }^{1}$

Daha sonra toplanan Berlin Kongresi de Ermeni meselesini, Berlin Antlaşması̀nın altmış birinci (61.) maddesine (Islahat) adıyla koyarak kabul etmiștir. İngiltere de Rusyảnın Doğu Anadolu'ya el atmasını önlemek için Ermenilerin "savunmasını" kendi üzerine alıyordu. Bu altmış beşinci madde ile tüm Avrupa’nın Hıristiyan devletleri sslahat bahanesiyle bağımsız bir Ermeni devleti kurmak için Osmanlı Devleti'ni zorlamaya başladılar. Ermeniler bütün bunlardan umutlanarak 1878 yılından İkinci Meşrutiyet'in ilanına kadar Anadolu'nun çeşitli yerlerinde ve İstanbul'da kanlı ayaklanmalar çıkardılar. 1908'den 1914 tarihine kadar gizli ve açık bir şekilde komite faaliyetleri görüldü. Taşnaksutyun komitesi 1908 tarihli programında Türkiye hakkındaki siyasetini şöyle gösteriyordu:

\section{Türkiye Ermenistaninda:}

1. Osmanlı Devleti hudutlarında mahalli ve geniş bağımsızlık ve federasyon temaları üzerine kurulan siyasi ve iktidari bir hürriyet olacaktır.

2. Merkezi hükümet demokrat halk temsilcilerinden oluşmuş bulunacak, Osmanlı hükümetinin bütün işlerini diş siyaset, askerlik, maliye, gümrük, posta-telgraf idare edecek, devletin diğer hizmetleri mahalli bağımsız bölgelere bırakılacaktır.

1 Ayastefanos Andlaşması 16.maddesi: Ermenistan'da "mahalli menfaatlerin gerektirdiği sslahat" yapılacak ve Ermeniler, Kürtlere Çerkezlere karşı korunacaktı.(Armaoğlu, 1999,522).
3. Türkiye Ermenistan’, Osmanli Federatif Devletinin bir kısmı olması bakımından iç işlerinde özgürlüğe kavuşacak ve onun bölgeleri içinde bulunacak halkın iç işleri de, mahalli bağımsızlıktan istifade edecektir.

4. Türkiye Ermenistaninın, gerek merkezi ve gerek özel kısımlarına ait kanuni-idari bütün kuruluşları, ırk, din, cins farkı olmaksızın genel, eșit, dolaysız, gizli ve orantı esaslarina dayanan oylarla seçileceklerdir. (Uras, 1976, s. 574)

Hükümete bu tür samimi bir davranış gösteren komiteler ilk iş olarak silahlanma, savunma tertibatına başladılar. Hınçak, Taşnaksutyun, Reforme Hınçak bir taraftan bütün güçleriyle taraftarlarını donatmaya çalışırken diğer taraftan da patrikhaneye, kiliselere, milli kuruluşlara el attılar. Komitelerin faaliyetlerinin içyüzünün farkına varamayan Osmanlı hükümeti ise başlangıçta bunlara yardım dahi ediyordu. Rusya'dan komitelere karşı şiddetle yapılan takiplerden kaçan komiteciler Türkiye’ye sığınıyorlar ve iyi bir kabul görüyorlardı.

Trablusgarp’ın işgali, Balkan Savaşı, Osmanlı hükümetini önemli ölçüde sarsmıştı. Ermeniler için bu durum çok önemli firsattı. Katagikos başta olmak üzere patrikhane, Ermeni politikacıları, Rusyảnın müdahalesiyle yeni baştan doğu illerinde sslahat sorununu ortaya çıkardılar. 1913 yılında Köstence'de toplanan Hınçak komitesinin yedinci kongresi açıktan açığa Türkiye’ye karşı düşmanlığa başlanmasına karar verdi.(Uras, 1976, s. 580).

1914 yllındaki önemli bir gelişme daha Ermeni meselesini farklı bir boyuta taşıyacaktı. Rusların ısrarı sonucu dönemin Osmanlı hükümetinin kabul etmek zorunda kaldığı Yeniköy antlaşmasına göre; Ermenilerin yaşadığı Doğu vilayetlerinde iki adet yönetim birimi kuruluyor ve bunların başına da güya tarafsız Avrupalı yöneticiler atanıyordu. Neyse ki I. Dünya Savaşının Ağustos ayında Avrupa da patlak vermesiyle anlaşma uygulanamadı. Hatta diyebiliriz ki, Osmanlı Devleti sırf bu anlaşmayı yırtabilmek için I. Dünya Savaşı'na girmekte acele etti. Ne var ki $1 \mathrm{Ka}-$ sım 1914 itibarıyla Osmanlı topraklarına saldıran Rus birliklerinin yanında tekrar Ermeniler olacak, hatta gizli örgütleriyle cephe gerisinde Müslüman köylerini basarak bir yandan şiddet ve korku yaymaya çalışırken diğer yandan da Türk ordusunu arkadan vurmaya çalışacaklardır (Taş, 1998, s. 923-968). Bunun 
neticesinde ise Osmanlı yöneticileri önce 24 Nisan 1915'te Ermeni komitacılarına ilişkin tutuklama kararı alır, yaklaşık bir ay sonra ise 27 Mayıs'ta tehcir kararnamesi çıkarılır.

Türkiyede konuya farklı yorumlar getirenlerden birisi olan Taner Akçam, tehcirle ilgili olarak "ahlaken mahkum edilmesi gereken yanlış bir eylem" nitelendirmesinde bulunur (Akçam, 2005, s. 328).

Tehcir hadisesine Ermeni tarafının yaklaşımını anlamaya çalışmak açısından dönemin Ermenistan Başbakanı Kaçaznuniınin raporuna bakmak yeterli olacaktır: "1915 yaz ve sonbahar döneminde Türkiye Ermenileri zorunlu bir tehcire tabi tutuldu, kitlesel sürgünler ve baskınlar gerçekleştirildi. Bütün bunlar Ermeni meselesine ölümcül bir darbe vurdu. Tarihsel Ermenistan`ın, bize devreden gelenekler ve Avrupa diplomasisinin vaatleri doğrultusunda, bağımsızlığımızın temelini oluşturması gereken bölgeleri boşaltıldı; Ermeni vilayetleri Ermenisiz kaldı. (Kaçaznuni, 2005, s. 32)"

Ermeni meselesinin kısaca özetlemeye çalıștığımız tarihi boyutu hakkında pek çok eser kaleme alınmıştır. Bunların bir kısmı Türk bakış açısını yansıttığı gibi belki de çoğunluğu Ermenilerin lehinde yayınlardan oluşmaktadır. Günümüzde Türk-Ermeni meselesinin diğer bir odağı da Azerbaycan'dır. Azerbaycan’ın konuya yaklaşımı hakkında da farklı eserlere rastlamak mümkündür. Örneğin Nesrin Sarıhmetoğlu’nun ve Beşir Mustayev'in çalışmaları ilk akla gelenlerdir². Türkiye Cumhuriyeti Başbakanlık Devlet Arşivleri Genel Müdürlügüünün Azerbaycan Milli Arşivi'yle ortaklaşa gerçekleştirdiği "Azerbaycan Belgelerinde Ermeni Sorunu" başlıklı eser de, 1918-1920 yılları arasını kapsadığı için yine 1915 olaylarına doğrudan değinmemektedir (DAGM,2011). Bu eserleri tamamlayıcı nitelikte olmak üzere Ermeni meselesine dair 1915 yilı Azerbaycan basinına yansiyan haberlere ve bunlardan çıkarılacak yorumlara değinmenin yararlı olacağını kuşkusuzdur.

2 Bkz. Nesrin Sarıhmetoğlu, Azeri-Ermeni İlişkileri (1905-1920), Ankara 2006; Beşir Mustafayev, Ermenilerin Kuzey Azerbaycan'daki Faaliyetleri (1905-1920), (2009). (Basılmamış Doktora Tezi), Ege Üniversitesi Türk Dünyası Araştırmaları Enstitüsü, Türk Tarihi Ana Bilim Dalı, İzmir, s. 132-136, 196-199.

\section{Ermeni Savaş Propagandası}

Ermeniler, asırlarca Türklerle adeta kardeş gibi yanyana yaşamış, kendilerine tanınan hakları sonuna kadar kullanarak Türk topraklarında maddi ve manevi pek çok bakımdan gelişme imkânı bulmuşlardı. Ancak emperyalizm çağ ${ }_{1}$ olarak adlandırabileceğimiz XIX. yüzyılda batılı büyük güçlerin çıkarları doğrultusunda yaratılan Şark meselesinin bir enstrümanı olarak Ermenilerin de kullanılması gündeme gelmiști. Bunun için en uygun ortam ise romantik milliyetçilik duyguları kılıfında, karşıtlık fikri üzerinde yükselen, nefret söylemleriydi. Nitekim Ermeniler XIX. yüzy1ldan itibaren yayınlarında Türk karşıtlığına dayanan yoğun bir propaganda faaliyetine giriştiler. Bunların çoğu Osmanlı ülkesi dışında Avrupa ülkeleri ve Amerika gibi bölgelerde hazırlanıp yurda sokuluyor, azınlık veya misyoner okullarında Ermeni gençlerine empoze ediliyordu. (Halaçoğlu, 2009, s. 129-152). Ayrılıkçı propagandanın beslendiği diğer bir kaynak ise basın-yayın organlarıyd.

Azerbaycan basınına yansıyan çeviri haberlerden bir kısmı Ermenilerin savaş propagandası yapmak amacıyla kaleme aldığı yazı örneklerinden oluşmaktadır. I. Dünya Savaşı́nda kendi hedeflerine ulaşmak için Ruslara destek olan Ermeniler, Türklerle mücadelelerinde yüreklendirilmeye çalışılmaktadır. Horizon gazetesinde "Bahadırane Ceng" başlığıyla yer alan yazıda öncelikle konunun tarihsel arka planına atıf yapilarak deniyor ki, "Berlin Kongresinden sonraki 1895 Ermeni ayaklanmasinda hürriyet kapımıza kadar gelmişken bu kıymetli misafiri içeri almayı başaramamıştık. Bunda İngiliz zırhlılarının Ağrı’nın zirvesine çıkmaması etkili olmuştu. 1908 meşrutiyet hareketinde asırlardır beklediğimiz rüyanın gerçekleşeceğini zannettikse de buna da düşmanliklar engel oldu. Ancak şimdi beklenen an gelmiştir...". Yazının devamında ise pek çok Ermeni gencinin cephede hayatını yitirdiği, pek çoğunun da yaralanarak zor durumlarda kalmasına rağmen bunlarla övünmekle yetinmeyip mücadeleye devam etmeleri ögütleniyor ve onları yüreklendirmek amacıyla şu hikâye aktarılıyor: "Bir gün İştifan (İstepanos) denilen Ermeni kahramanlarindan biri Türkler ile ettiğgi vuruşmada mağlup olarak validesi huzurunda müracaat edip kapını döğüp çı̆̆ırd. 'Ana aç kapını oğlun mecruh (yaralı) ve vuruşmadan mağlup olarak kayıtmıştır(geri dönmüşstür).' Anası 
cevaben 'sen benim oğlum değilsen. Benim oğlum mağlup olmaz' demiştir... Bu sözden sonra İştifan hemen halette yine geri kaytıyor șiddetli bir tokuşmadan sonra düşmana galip olarak eve kaytıyor.

Koy (bırak) Ermeni anaları da bunun gibi öz sevgili evlatlarina yol verip kapıdan eve koymasinlar. Koy Ermeni anaları da öz evlatların harbe doğru itelesinler. Tâ ki üzerinde Ermeni yazılmış bayrak Ararat Dağı'nın kellesinde kol kanat açıp ihtizar etsin (huzura çıksin)."(Yeni İkbal 12 Ağustos 1915).

Yayınlanan yazıların bazılarından da anlaşılıyor ki bütün Ermeniler savaş düşüncesinde hemfikir değillerdir. Örneğin, savaşı eleștiren bir yazıda sadece fakir Ermenilerin askere alındığ 1 ve ölmeye özendirildiği ileri sürülüyordu. Öte yandan zengin olanların ise kıllarını bile kıpırdatmadıkları hatta savaş nedeniyle zor duruma düşen insanlara yardımda bulunmaktan bile çekindikleri belirtiliyordu. (Yeni İkbal, 9 Ağustos 1915). Aynı cümleden olmak üzere Ermeni din adamlarının "rahat yaşamlarından ve güvenli s1ğınaklarından ayrılmadan savaş çığırtkanlığı yapması” da eleştiriliyordu (Yeni İkbal, 4 Ağustos 1915).

Ermeni yazınına baktığımızda ortaya çıkan yazı, şiir ve mektuplar incelendiğinde Ermeni olaylarının ortaya çıkışına dair çok önemli ipuçları yakalanabilir. Propaganda amaciyla hazırlanan ve milli duyguları pekiştirici hikâyelerle Ermeniler arasında Türk ve İslam düşmanlığı aşılanmaya çalışılmıştır (Halaçoğlu, 2014, s. 159-177).

\section{Tehcir Kararı ve Yaşananlar}

Öncelikle "tehcir" kelimesi Osmanlı tarih terminolojisinde bugünkü tabirle tam olarak "ülke içinde bir yerden başka bir yere nakil anlamını taşıyan "zorunlu göç" karşıllğ̆ında kullanılmış olup, Osmanlı Devleti’nce Ermenilerin zorunlu göçü, belgelerde "Sevk ve İskan" olarak adlandırılmıştır. Bu sebeple "tehcir"in anlamı çoğu kimselerin ve özellikle Ermeni diasporasının kullandığı yurt dışına çıkarma anlamındaki "deportation"la aynı değildir. Zira Ermeniler, yine Osmanlı Devleti'ne ait olan topraklara nakledilmişlerdir. (Halaçoğlu, 2008, s. 27)

24 Nisan 1915’te Osmanlı Dâhiliye Nezareti, Ermeni komite merkezlerinin kapatılması, evrakına el konulması ve komite elebaşlarının tutuklanmasını emret- miştir. 26 Nisan'da da Başkumandanlık birliklere aynı mealde bir duyuruda bulunarak elebaşların askeri mahkemelere sevki ile suçluların cezalandırılmasını talep etmiştir. Dahiliye Nezaretinin bu talimatı üzerine yaklaşık bir ay içinde Osmanlı topraklarında 2345 kişi tutuklanmıştır. Ermenilerin her yıl "soykırım" tarihi diye gösteri yaptıkları 24 Nisan aslında bu tutuklama günüdür.(Gürün, 2012, s. 319). Bunun akabinde olayların devam etmesi ve özellikle Doğu Cephesi için tehlike arzetmesi üzerine 26 Mayıs 1915'te Başkumandanlık, Dahiliye Nezaretine aşağıdaki şekilde bir yazı yollar:

"Ermenilerin Doğu Anadolu vilayetlerinden, Zeytun'dan ve buna benzer yoğun bulundukları yerlerden Diyarbekir vilayeti güneyine, Firat nehri vadisine, Urfa, Süleymaniye yakınlarına gönderilmeleri şifahen kararlaştırılmıştı. Yeniden fesat yuvaları meydana getirmemek için Ermenilerin göç ettirilmesinde şu düşünceler esas alınmıştır:

1. Ermeni nüfusu gönderildiği yerlerdeki aşiret ve İslam sayısının \%10 nisbetini geçmemelidir.

2. Göç ettirilecek Ermenilerin kuracakları köylerin her biri elli evden çok olmamalıdır.

3. Ermeni göçmen aileleri seyahat ve nakil suretiyle de olsa yakın yerlere ev değiştirememeli." (Gürün, 1983, s. 213).

Enver Paşảnın Talat Paşàya yolladığı 2 Mayıs 1915 tarihli yazıda, Ermenilerin isyanları sürdürme için daima toplu halde olduklarından, ya bunların Rusların Müslümanlar için yaptığı şekilde, Rus topraklarına sürülmesi gerektiği yahut Anadolu içine dağıtmak lüzumunu ileri sürdüğü görülmüştür. Enver Paşa’nın istediği Ermenilerin isyan çıaramaz hale getirilmeleri idi. Eğer bunlar hep bir arada olacak yerde, ufak üniteler halinde ve birbirlerinden uzak yerlerde yerleştirilecek olurlarsa isyan edebilme şansları kalmayacaktı. Tatbikat da isyan ve haydutluk mihrakları için düşünülmüştü.(Gürün, 2012, s. 317).

26 Mayıs 1915’te Ermeni ayaklanmaları ve tehcirine dair Dahiliye nezaretinden sadarete bir tezkere gelir ve 30 Mayıs günlü Bakanlar Kurulu toplantısında bu işler üzerinde verilen karara temel teşkil eder. Sözkonusu tezkerenin ayrıntıları hakkında Yusuf Hikmet Bayur'un eserine müracaat edilebilir (Bayur, 1991, s. 37). 
Nitekim bölücü faaliyetlerinden dolayı Osmanlı bürokrasisinde görev alan Ermenilerin faaliyetleri de basina yansiyan haberler arasındaydı. Yeni İkbal gazetesinin yazdığına göre, İstanbul'da yaşayan tanınmış Ermenilerden Bogos Nubar Paşa askeri mahkemeye davet edilerek Türkiye’nin doğusunda bağımsız bir Ermenistan kurmak için İtilaf devletleriyle işbirliği yapmak ve Ermeni kilisesinin kışkırtmasıyla Türkiye aleyhine adam ve para toplamaya çalışmakla suçlanmıştı. Sonuçta Paşảnın mallarına el konulmuş, sahip olduğu devlet nişanları geri alınarak tutuklanmıştı. (Yeni İkbal, 22 Ekim 1915).

Romanya, Avusturya ve Fransa gazetelerinde Türk konsolosunun verdiği demece göre Ermeni tehciri ile ilgili olarak günümüze kadar süren tartışmalara cevap olabilecek nitelikte ipuçları bulmak mümkündür. Buna göre Avrupa kamuoyunu yanlarına çekmek için pek çok ülkede çıkan gazetelerde; Türklerin Ermenilere baskı yaptığı haberleri yayılmıştır. Halbuki kanıtlardan anlaşılacağı üzere Ermeniler eskiden beri isyan hazırlığında idiler. Nitekim Şebinkarahisar olayında beş yüz Ermeni askeri isyancılarla birleşerek yüz elli Türk askerini öldürüp şehri ateşe vermiştir. Osmanlı hükümetinin soğukkanlılıkla meseleyi çözmek istemesine rağmen Ermeniler bu girişime gülle ve mermilerle cevap vermişlerdir. Bu yüzden Osman$l_{1}$ yönetimi suçsuz Ermenileri isyan bölgelerinden uzaklaştırıp sakin bir hayat sürecekleri yerlere göndermeyi amaçlamıştır. Bu uygulama birçok zorluklar getirse de ayaklanmanın bastırılıp düzenin yeniden tesis edilmesi için son derece gereklidir.(Yeni İkbal, 20 Ağustos 1915).

Tehcirin yaşandığı günlerde özellikle Ermeni ve Rus basınına yansıyan haberlerde Türklerin birçok yerde Ermenilere katliam yaptığı haberleri görülmekteydi. Hatta Ermenilerin ateşe atıldığ 1 , çocukların esir edilip kadınların tecavüze uğradığı haberleri yayılıyordu. Oysa bu haberlerin çoğunun aslının olmadığı yine bir Ermeni yazarın gazetesine verdiği haberden anlaşılmaktadır: "On beșten çok Ermeni kasabalarının adını zikrederek bu yerlerde ebeda Türklerin kırgın salmadıklarını beyan ile Ermenilerin bu hususlarda nahak yere heyecana düşmemelerini arzu ediyordu." Nitekim Osmanlı hükümeti de bu haberlerin asılsız bir şekilde çıkarıldığını ya da olayların abartılarak bir savaş propagandası malzemesi olarak kullanıldığından yakınmaktaydı. (Basiret, 4 Temmuz 1915).
"Aref" gazetesinden alıntı yapan Yeni İkbal; tehcire tabi tutulan Ermenilere yardım edilmesi hususunda çağrıda bulunurken diyor ki; "sürgünlerin vatanlarına dönüşleri ve bu azap yolunda soğuk ve açlıktan çektikleri dayanılmaz eziyetlerin yanında Kürt saldırılarında verdikleri kayıplar eklenmektedir. Ermenistan'ın bu sürgünlere yardımda aciz kalması onların tekrar eski topraklarına cehenneme dönmesine neden olmaktadır". Ermenistan'da yaşayan herkes mevkiine bakmaksızın bir anlık dahi olsa kendisini bu sürgünlerin yerine koymalı ve onlara yardım eli uzatmak için daha çok gayret göstermelidir (Yeni İkbal, 22 Ekim 1915).

Russkoye Slovo (Rus Sözü) gazetesinden aktarılan Ermeni Tehciri ile ilgili haberler gerçekten dikkat çekicidir:

\section{"Ermenilerin Köçürülmesi}

Mevsuk menbalardan alınmış olan haberlerden anlaşıldiğına göre Osmanl Ermenistanindaki Ermeni ahalisinin göçürülmesi meselesi tamam olmuştur. $\mathrm{Ha}$ lep -Musul hattı üzerinde 400 - 500 bin Ermeni toplanmıştır. Ermenilerin göçürülmesi Almanların planı üzere icra edilmiştir.

Almanların planina göre Rusya serhaddi Türkiye İran ve Afganistan'dan ibaret bir Müslüman deryastyla ihata olunmalıdır. Bu Müslüman deryasından bitmez tükenmez bir derecede bir kuvvet istihsal olunabilir. Almanlar bu husustaki teşkilatı bir senede tamam edebileceklerini kaviyyen ümid ediyorlar.

Daima Rusya tarafina meyl eden Ermeni ahalisi ile meskun olan yerlerini bir kılıç gibi İslam deryasına sokulmuş olduğundan Almanlar kendi planlarının birahmane bir surette icra ve tatbikinde inad ve israr ediyorlardı." (Açık Söz, 16 Aralık 1915).

Osmanlı Devleti bilindiği gibi I. Dünya savaşına Almanya ile ittifak yaparak girmişti. Bir anlamda kader birliği yapılmıştı. Ancak bu ittifaktan en fazla faydalanan tarafın Almanya olduğuna hiç şüphe yoktu. Zira Doğu'da hem Ruslarla hem de Akdeniz ve Ortadoğu'da İngilizlerle savaşa tutuşulması Batı'da sıkışan Almanlara rahat bir nefes aldırmıştı. Ne var ki bütün bu ortaklığa rağmen Almanlar, Türkleri kolay feda edilecek bir müttefik olarak görmeye devam ettiler. Yukarıdaki haberden net bir şekilde anlaşıldığı gibi tehcir hareketi başta Almanların fikri iken 
Berlin'de Talat Paşa'nın bir Ermeni tarafından suikastle şehit edilmesi yine aynı Almanlar tarafindan mazur görülmüştür. Öte yandan yukarıdaki haberin düşündürdüğü bir başka gerçek daha vardır ki o da tehcir sırasında hayatını kaybeden Ermenilerin miktarına ilişkindir. 1914 yılında Türkiye’nin Ermeni nüfusu 1.300.000 iken göçe tabi tutulan Ermeni sayıs1 702.900 civarındadır.(Gürün, 2012, s.339). Bütün bu gerçeklere rağmen çeşitli kaynaklarda 1.500.0001.800.000 Ermeni'nin tehcir sırasında hayatını kaybettiği iddia edilmektedir. Öncelikli olarak belirtilmesi gereken husus tehcir kararının bütün Ermenilere uygulanmadığıdır. Katolik ve Protestan mezhebinden olan Ermeniler göç ettirilmemiştir.

3 Aralık 1915 tarihli “Açık Söz” gazetesinde ise "Russkoye Slovo" gazetesinden yapilan alıntıda HalepMusul hattında 400-500 bin Ermeni'nin toplandığ yazılmıştır. Bu iki bilginin karşılaştırılması halinde aradaki farkın en fazla 200.000 civarında olduğu görülmektedir. Bu rakam "sözde Ermeni soykırımı" iddialarında verilen 1.500.000 insanın hayatını kaybettiği varsayımıyla açık bir şekilde çelişmektedir.

\section{Van Olayları}

Sevk ve iskân kararının alınmasının sebeplerinden birisi de 15 Nisan 1915 tarihli Van isyanıdır. Sevk ve iskân kararı Rumî takvime göre 14 Mayıs 1331, miladî takvime göre 27 Mayıs 1915 tarihinde alınmıştır. Ermeniler sevk ve iskâna tâbi tutuldukları için isyan etmemişlerdir. İsyan ettikleri için sevk ve iskâna tâbi tutulmuşlardır.(Çelik, 2003, s. 5).

Amerikalı tarihçi Stanford J. Shaw’a göre, "Ermeniler 28 Nisan günü Erivan'dan ayrılıp 14 Mayıs'ta Van’a girmiş, genel bir katliam düzenleyip, izleyen iki gün boyunca, yerel Müslüman halkı öldürmüşlerdir.Rus himayesi altında Van'da bir Ermeni devleti kurulmuştur. Bu devlet, ölen ya da kaçan Müslüman halkın ortadan kaldırılmasından sonra da devam edecek gibi görünüyordu.” (Maleville, 2003, s. 28)

Van Askeri Komutanı Sadettin Paşa'nın kaleme aldığ raporda olayların gelişimi ayrıntılı olarak anlatılırken bu isyanın sonucunda "Van içinde vuku bulan telafat ve yaralı yekunu 879'dur. Bunun 340 ölü, 260 yaralıs1 Müslüman'dır. Ermenilerden 219 ölü ve 59 yaralı vardır." (Gürün, 2012, s. 245-246) denmekteyken Van olaylarında en fazla zarar gören tarafın Müslümanlar olduğunu vurgulamakta yarar vardır.
"Yeni İkbal” gazetesinin “Mşak” isimli Ermeni gazetesinden yaptığı alıntıda 1915 Van olaylarının çıkışı şu şekilde açıklanmaktaydı; başlangıçta iyi geçinen Türkler ve Ermenilerin arasının açılmasına neden olan olay Rusların saldırısı ve Ermenilerin onlara verdiği destektir. Osmanlı yönetimi askerlikten muaf oldukları halde bir kısım Ermenileri silah altına almıştı. Ancak Rusların Saray ve Başkale'ye yaptıkları baskınlarda Ermenilerin ihanet ettikleri şüphesi üzerine ilişkiler gerilmişti. Bunun üzerine Van şehrindeki Ermenilerin silahları toplanmış ve bir kısmı da firar etmişti. Gerginliğin artması üzerine 4 Nisan'da Şadah olayı yaşandı, çatışmalar arttı. Bunun üzerine çevredeki Ermeniler de birleşmeye çağrılarak oluşturdukları askeri kuvvet Nisan'ın altısı ve yedisinde çatışmaya girdi. Ermeniler iki kayıp verdiler. Türk ve Kürt askerlerine karşı Ermenilerin direnişi Nisan ayının sonlarında Rus ordusunun yaklaşmasına kadar sürdü. Sonunda Türklerin geri çekilmesiyle birlikte Mayısın dördünde Van'a giren Ermeni birlikleri Müslümanların evlerini yaktı.(Yeni İkbal, 26 Ağustos, 1915).

Van’ın Ruslar tarafından ele geçirilmesini kendi zaferleri gibi kutlayan Ermeniler, bu başarının kendilerini atalete düşürmesinden de endişe duymaktaydilar: "Rus ordusu Van'a dahil olanda 'Van azad oldu', 'Ermeniler'in asırlarla olan dilekleri tecessüm etti', 'Vaspurakan siyaset hasebince azad oldu', 'bizim asırlarla olan düşmanımız müzmahil oldu' diye kışkırtmaya başladık. Ermeni cemaati de bugün laylaları (ninnileri) işitip Van'ın azad olmasından ilave hakimi de (yöneticisi) Ermeni olduğunu bilip yine başlarını yastığa koyup uyumaya başladılar." (Yeni İkbal, 10 Ağustos 1915).

Mşak gazetesi kaynak gösterilerek verilen haberde Van şehrini kimlerin yaktığı ve olaylara kimlerin sebebiyet verdiği bir itiraf gibi aktarılmaktadır. Buna göre; Van vilayetine idareci olarak atanan Dermen, Ekim'in yedisi Çarşamba günü akşam vagonuyla Üçkilise'ye sonra da Iğdır yoluyla Van'a hareket etti. Ona, Armenak Yakarıyan'ın eşkıyaları ile iki yüz kişiden ibaret olan Van gönüllüleri ve yüz kişilik Kazak birliği eşlik ettiler. Van’n yeni idarecisi Ermeni cemaatini kendi vatanlarına ocaklarını şenlendirmeye çağırmaktaydı. İşte bu sebeple Van ve Vasbodakan firarilerinden birçoğu kendi yerlerine dönmeye başladılar. Lakin bunlar kışı nerede geçireceklerdi. "Yanmış harabelerde ya da uçmuş evlerde mi? Acaba kim 
bunları uçurup yandırmıştır. Türkler mi, Kürtler mi? Ya da Cevdet mi? diye edilen suale Mşak şöyle cevap veriyor:

Açık danışak, Van gönüllülerinden huzur o mektuba şahadet veriyorlar ki Van’in evvelinci kaçkın zamanınin son günlerinde Cevdet Bey ile Türkler henüz Van'a dahil olmamıştan kabak (önce) Duşenbe (pazartesi) gününden Pencşenbe (Perşembe) gününe dek Van’ın en güzel ve mamure evleri mahz Ermeni gönüllülerinin eliyle yangına dönülmüştü. Gönüllülerin olduğu gibi Van'ın eski hakimi Aram da şeksiz bu hali, bu yangını görüyormuş. Acaba niçin ve ne maksat ile yazık Ermenilerin olup olan sığınacakların böyle yandırdılar veya inki bu siyahini (listeyi) tertip verenler kimlermiş?" (Yeni İkbal, 13 Ekim 1915)

Van düştükten sonra Rus Çarının 18 Mayıs 1915’te Beyazıt bölgesi Rus askeri Komutanlığ 1 yolu ile bir telgraf göndermiştir: "Van halkına fedakârlığı dolayısıyla teşekkürlerimi bildiriniz." (Gürün,2012, s.335). $\mathrm{Bu}$ telgraftan da anlaşılacağı üzere Van olaylarının yaşanmasından en fazla istifade eden taraf Ruslar olmuştur. Dolayısıyla Van'daki Ermeni isyanının amacı da net bir şekilde ortaya çıkmaktadır.

\section{Ermenilerin Komşuları ve Diğer Topluluklarla illişkileri İtilaf Devletleri ve Ermeniler}

Osmanlı Devleti, I. Dünya Savaşı'na Almanya’nın yanında katıldığı için hiç şüphesiz İngiltere ve Rusya, Türklere karşı Ermenileri kullanmanın yollarını aramaktaydı. Yeni İkbal gazetesinin İsviçre gazetelerinden yaptığı bir alıntıda Talat ve Enver Paşaların konu hakkında değerlendirmelerine yer verilmekteydi. İngilizler bu olayların arkasındaki en önemli güçtü. Türkiye'yi içeriden çökertmek için bir ayaklanma başlatmak peşindeydiler. Rusya’nın Osmanlı hakkındaki niyetleri de aynı plana dayanmaktaydı. Nitekim Ermenileri silahlandırarak onları isyana teşvik ediyor Osmanlı yönetimi de bu isyanlara meşru bir şekilde müdahale edince Avrupa kamuoyunda Ermenilere soykırım yapılıyor şayiasını yayılıyordu. Osmanlılar cesur oldukları kadar da halim bir cemaattirler. Kendilerine kötü davrananlara son ana kadar sabır gösterebilirler. Ancak Rus ve İngilizler insancıllık kisvesi altında her türlü kandırmacayı yapmakla tanınırlar. Amerikalılar ise Türkiye ile düşmanlık yaşanmaması için bu meselede tarafsız kalmak zorundadır. Almanya'ya gelince onlar da üçüncü bir devletin sözüyle müttefiki olan Türkiye’nin iç işlerine müdahaleye kalkmamalıdır. Nitekim düşmanlarımız Washington'la aralarını iyi tutmak adına Türkiye ile Almanya’nın arasını açmaya çalıştıkları gözden kaçırılmamalıdır. (Yeni İkbal, 23 Kasım 1915).

I. Dünya savaşı sırasında Osmanlı Devletiyle müttefik olan Bulgaristan'in da Ermenilerle arasının pekiyi olmadığ 1 anlaşılmaktadır. Nitekim bir haberde Türkiye'den kaçıp Bulgaristan'a sığınan Ermenilerden 115 kişinin Osmanlıyya iade edildiği ve bazılarının da Bulgarlar tarafından siper kazmaya zorlandığı yans1maktadır (Basiret, 14 Kasım 1915).

\section{Ermeni-İran İlişkileri}

Rusyảnın Ermenileri Osmanlı Devleti'ne karşı kullandığını yukarıdaki farklı örneklerle vurguladık. Aynı şekilde İran'daki Rus etkisinin artması da daha sonra kendisini Ermenilerle ilişkilerde hissettirecektir. Bunun yanısıra İran’n Ermeniler'e karşı tutumunda Osmanlı ile olan mezhep uyuşmazlığının da etkisi görülmektedir. Bunun sonucunda çeşitli yollarla "konsoloslukları aracılığıyla pasaport temini ve himaye ederek, İran içinde lojistik destek sağlayarak ve İran sınırlarını rahatça kullanmalarını temin ederek" destek oldukları görülmektedir (Bolat, 2009, s.232).

Ancak olayların akışının daha sonra İran’ı da tehdit eder bir hale dönüşmesi İran’’n da konuya bakışını değiştirmiştir. Çünkü Ermenilerin "Büyük Ermenistan" hayalinin içinde Türkiye, Azerbaycan ve İran toprakları bulunmaktadır (Özkan, 2014, s.186).

İran basınına yansıyan haberleri de değerlendiren Basiret gazetesi, Vasporokan bölgesinde Rus ve Ermenilerin birlik olarak vahşet uyguladıklarını buna karşın Türklerin halkı galeyana getirmemek adına Ermenilerin bu vahşetini gizlediklerini yazıyor (Basiret, 25 Temmuz 1915).

Başka bir sayıda İran'da yaşayan Ermeniler ve onların yapması ve yapmaması gerekenler tavsiye niteliğinde yer almaktadır.

İran I. Dünya savaşı yıllarında etkisiz bir konumda, İngiliz ve Rus politikalarının etkisiyle ekonomik ve siyasi olarak ikiye ayrılmış durumdadır. İran'da iktidar sahipleri ise ülkenin bütünlüğünü korumaya çalış- 
maktadırlar. Böyle bir ortamda İran'da yaşayan Ermenilerin durumu da dikkat çekicidir. Gazetelerde yer alan yorumlara göre İran'daki Ermenilerin olumsuz bir hareketi büyük kayıplara yol açacaktır. Nitekim İran Demokrat Fırkası temsilcileri Ermenilere tarafsız kalmaları hususunda tavsiyede bulunmaktadırlar. $\mathrm{Bu}$ itibarla Ermeniler yakın tarihlerde yaşananlardan dersler çıkarmalı ve Türkiye'de yaptıkları hataları tekrarlamamalıdır. Kısacası İran'daki Ermeniler buradaki çıkarlarını düşünerek hareket etmeli "Sonuç vermeyecek romantik hayallerden" kaçınmalıdır (Yeni İkbal, 17 Aralık 1915). Buradaki ifadelerden de açıkça anlaşılmaktadır ki, İran, Ermenilerin Türkiye'deki emellerinden haberdardır. Benzer isteklerin İran tarafından da hoş görülmeyeceğini belirterek açıkça uyarıda bulunulmaktadır. Buna rağmen İran yönetimi İran'daki Ermenilerin tarafsız kalabileceğine inanmamakta ve Ruslar gibi Ermenileri de düşman olarak değerlendirmektedir (Basiret, 19 Aralık 1915).

\section{Ermenilerin Diğer Topluluklarla İlişkileri}

"Horizon" gazetesinden yapılan diğer bir alıntıda Ermenilerin Gürcülerle olan ilişkisi ve Kafkasya’ya yerleştirilmeleri konularına değinilmektedir. Buna göre Kürt kılıcından kaçarak Kafkasya’ya sığınan Ermeniler zor durumdadır. Gürcüler kendilerine sahip çımamakta ve Ermenilere yardım etmekte çekimser görünmektedir. Hatta " birçok Gürcüler Ermenilere Enver ve Talat mesabesinde 'eșeğe gücü yetmeyip semerini tokatliyor' mesel-i meșhurun anlaşılmasına mazhar oldular" denmektedir. Oysa Kafkasya’nın en eski ahalilerinden olan Ermenilerin vaktiyle bölge insanları için yaptığı yararlı işlerden örnekler verilmektedir. Buna karşın Osmanlı Kafkaslardan göç eden yüz binlerce Çerkez, Çeçen, Abaza, Noğay ve Müslüman Gürcülere yer verirken Ermenilerin Kafkasya'da istenmemeleri anlaşılmaz bir durum olduğu ileri sürülmektedir (Yeni İkbal, 8 Aralık 1915). Yukarıdaki ifadelerden de anlaşılacağı gibi Ermenilerin 1915 yılında sadece Türkiye ile değil Ruslar dışında bölgedeki diğer tüm halklarla meselesi bulunmaktadır.

Kaynaklar incelendiğinde Ermenilerin bölgede yaşayan Kürtlerden de nefret ettikleri sonucu çıkmaktadır. Yaşadıklarının sorumlusu olarak Türklerden çok Kürtleri görmektedirler. Nitekim bu bakışları çeşitli haberlere de yansımaktadır. Bir Ermeni kaynağından aktarıldığına göre Saray ve Şadah yoluyla Hoy’a gelen bin beş yüz Ermeni'nin yarısını yolda Kürtler katletmişler diğer yarısı da hasta ve yaralı olarak ulaşabilmiştir (Yeni İkbal, 10 Ağustos 1915).

\section{Sonuç}

Kendilerini "Hayk" diye isimlendiren Ermeniler ülkelerine de Hayastan adını vermişlerdir. 11.yüzyıla kadar Pers, Makedon, Selefki, Roma, Sasani, Bizans, Arap egemenliği altında yaşamışlardır. 11.yüzyılda Türklerle karşılaşmışlar ve 1877-1878 Rus Harbi ve Berlin Kongresi’ne kadar Türklerle barış içerisinde yaşamışlar. Berlin Kongresi sonrasında "Ermeni meselesi” ortaya çıkarılmış ve Ermeniler Osmanlı Devletỉne karşı isyanlara başlamışlardır. Birinci Dünya Savaşında ise Ruslara kılavuzluk edip Osmanlı Devleti’ne karşı savaşmışlardır. Bunun sonucunda Osmanlı Devleti "tercih kararı" alıp özellikle Anadolu'nun doğu vilayetlerindeki Ermeniler Musul'un güney kısmı, Zor ve Urfa Sancağı'na; Adana, Halep, Maraş civarından çıarılan Ermeniler de Suriye’nin doğu kısmı ile Halep’in doğu ve güneydoğu kısımlarına göç ettirilmişlerdir.

İtilaf Devletleri Mütarekeden sonra Osmanlı hükümetlerine kurdurdukları Divan-1 Harbi Örfileri bir koz olarak kullanma çabası içinde olmuşlardır. Bu süreçte görünüşte sadece Ermenileri sevk eden ve onlara karşı bir takım suiistimaller yaptıkları iddia olunan İttihatçıların cezalandırılmaları amaçlanıyor gibiyse de, gerçekte İtilaf devletlerinin menfaatlerine karşı çıkan herkesin cezalandırılmak istendiği ortaya çıkmıştır. Bunun en açık ispatı ise söz konusu bu mahkemelerin bir müddet sonra Mustafa Kemal Paşa dahil Milli Mücadeleye katılan ve destek veren herkesi yargılayacak olmasıdır. Ermeni taraftarları da bu firsattan yararlanarak "sözde Ermeni katliamının" sadece belli bir grup tarafından değil, bütün bir millet tarafından gerçekleştirildiği iddialarını da dile getirerek, Türk Milletinin tamamını suçlama gayretine girişmişlerdir. (Ata, 2005, s.274)

I. Dünya Savaşı sırasında Ermenilerin \%95'i Rusya (1.685.000), Türkiye (1.300.000) ve İran (80.000) olmak üzere üç devlette yaşıyorlardı. Rusya Ermenilerinin çoğu 1.612.000 kişi Kafkasya’nın sakinleri idi. Türkiye Ermenilerinin ancak yarıs 868.000 bin kişi Doğu Anadolu'da yaşıyordu. İran Ermenilerinin ise yarısı Azerbaycan vilayetlerinde yerleşikti. Şimdiki Ermenistan arazisinde Kafkasya Ermenilerinin sadece \%40’1 yaşıyordu. 1897-1913 yılları arasında Türkiye'den Güney Kafkasyàya tahminen 165.000 ile 185.000 Ermeni göç etmiştir. Bunlardan 26.000'i Erivan kazasına yerleştirilmiştir. Bir asırlık süre içinde Güney Kafkasya’da Ermeni nüfusunun oranı akıl almaz bir şekilde 1801 yılında \%7-8 iken 1914 yılın- 
da \%25’e kadar çıkmıştır. (Safarov,2002, s.210-211). 1914 yılının başlarında Güney Kafkasya nüfusu başlıca olarak üç etnik gruba ayrılmaktaydı 1.992.000 Azerbaycan Türkü başta olmakla toplam 2.382.000 Müslüman, 1.549.000 Ermeni ve 1.536.000 Gürcü idi. (Safarov, 2002, s. 167-172).

Dolayısıyla yukarıdaki rakamlardan da anlaşılacağı üzere, Ermeni meselesi sadece Türkiye’yi değil aynı zamanda Kafkasyảnın tamamını ilgilendiriyordu. Bölgede en kalabalık nüfusa sahip olan Azerbaycan da konunun dışında kalamazdı. Nitekim kamuoyunun görüşünü yansıtan basin organlarında Ermeni meselesine dair haberler ve yorumlar yer almaktaydı.

Elbette gazetelerde yer alan haberler sadece Azerbaycan kaynaklarına dayanmıyor, önemli bir kısmı Ermeni ajanslarının verdiği bilgilerden elde ediliyordu. 1915 yılı itibarıyla en fazla değinilen konuların başında Ermeni tehciri gelmekteydi. İlk olarak Ermeni tehcirinin sebebi olarak bağımsız büyük Ermenistan kurma hayalini gerçekleştirmek amacıyla propaganda faaliyetlerine önem verildiğini görüyoruz. Belirlenen bu bağımsızlık amacı için savaş sırasında Ruslarla işbirliği yapılması da tehcirin bir başka nedeni olarak öne çıkıyor. Haberlere yansıyan tehcirle ilgili diğer başlık ise rakamlardaki ihtilaftır. Buna göre, $o$ günün haberleri ile daha sonra ileri sürülen rakamlar arasında önemli farklar bulunmaktadır.

Azerbaycan basınında öne çıkan diğer bir başlık ise Van'da yaşanan olaylardır. Van şehrinin Türkler tarafından yakılmadığı tam aksine Ermeni çetelerinin işi olduğu, hatta bu olaylardan en çok Ermenilerin zarar gördügü açık bir itiraf olarak yer bulmuştur.

1915 yılında basına yansiyan haberlerin bir kısmı da Ermenilerin komşu diğer topluluklar ve Avrupalılar ile ilişkileri hakkındadır. Örneğin İran`ın taraf olmaktan çekindiği, hatta Türkiyede yaşananlara bakarak Ermenileri uyardığı görülmektedir. Öte yandan Gürcüler ile Ermenilerin arasının da iyi olmadığ anlaşılmaktadır ki, Ermeniler Kafkasyảnın asli unsuru olarak kendilerini görürken, Gürcüleri Osmanlı faaliyetlerine destekçi gibi nitelendirmişlerdir. İlginç diğer bir nokta da Ermenilere karşı saldırıda bulunanlar sıralanırken bazı yerlerde "Türklerle Kürtler" denmekte, ama birçok yerde de katliamlardan Kürtler sorumlu tutulmaktadır.
Savaş sırasında İngiltere ve Rusya’nın tamamıyla Osmanlı Devletini parçalamaya yönelik siyaseti belliyken en ilginç yorumlardan birisi ise Almanya hakkındadır ki, Ermeniler başlarına gelenlerin en büyük sorumlusu olarak Almanları göstermekte ve bunların Alman siyasetine ve menfaatlerine göre gerçekleştiğini iddia etmekteydiler.

1915 yılı itibarıly Azerbaycan da Ermenistan gibi Rus çarlığının yönetiminde olan bir bölgedir ve henüz bu iki grubun arasında önemli bir çatışma yaşanmamıştır. Azerbaycan'ın bu sırada olayları tarafsız bir gözle izlediği söylenebilir. Ancak savaşın seyrinin değişmesiyle özellikle 1918 yılına gelindiğinde Azerbaycan’ın da Ermenilerin hedefine oturduğu bilinmektedir. Nitekim Ermenilerin talepleri aradan geçen bir asra rağmen değişmemiş ve Türkiye ile Azerbaycan gibi iki kardeş topluluğun Kafkasya ve Doğu Anadolu üzerindeki egemenlikleri yine Ermeniler tarafından çeşitli yollarla tehdit edilmeye çalışılmaktadır. Ancak bütün yaşananlara rağmen en fazla zararlı çıkan tarafın Ermeniler olduğuna şüphe yoktur. Türkiye, Azerbaycan ve Ermenistan’ı paylaştıkları sınırlar itibarıyla jeo-stratejik önemi olan bir coğrafyayı paylaştıkları gözönünde bulundurulursa bölgedeki istikrarsızlıktan kimlerin faydalanacağı da açıktır. Aradan bir asır geçse de bu çıkar odakları değişmemiştir ki bunlar dünün emperyalist güçleri iken bugün kendilerini süper güç olarak adlandıran dünya liderleridir. Nitekim Sovyetler Birliği'nin on beş cumhuriyetinden birisi olan Ermenistan daha Şubat 1988'den itibaren Azerbaycan topraklarını işgal etmeye ve katliamlar yapmaya başlamıştı. Sovyetlerin 1991 yılında dağılıp bağımsızlığını kazanmasına rağmen aynı politikasını devam ettiren Ermenistan, bugün Azerbaycan toprağı olan Dağlık Karabağ ve çevresinde bulunan Azerbaycan’n 7 ilini işgali altında tutmaktadır. Sonuç olarak tarihte yaşananların sorumlusu aranacak olursa en iyi cevabı Ermeni politikacılarından Kaçaznuni vermektedir: "Artık Türkiye Ermenistanı diye bir şey yok. Büyük Avrupa devletleri bizleri defnettiler. Ermeni halkının yarısı kan kaybetmiş ve talan edilmiştir, uzun bir dinlenmeye ihtiyacı vardır. Ermenistan Cumhuriyeti, özerk bir bölge olarak Sovyet Rusya yla birleşmiştir; devletimizi Rusya ‘dan koparamayız, çok istesek bile bunu yapamayı ve yapabilecek olsak bile istemememiz gerekir. Parti, yenilmiş ve otoritesini kaybetmiştir; ülkeden kovulmuş ve geri dönemez. Kolonilerde ise yapacağı bir iş yok. Günümüzde durum bu."( Kaçaznuni, 2005, s. 86.) 


\section{Kaynakça}

\section{Gazete ve Dergiler}

Açık Söz, 8 Safer 1334, (1915,16 Aralık).

Basiret, 6 Ramazan 1333 (1915, 4 Temmuz).

Basiret, 25 Ramazan 1333, (1915, 25 Temmuz).

Basiret, 19 Muharrem 1334 (1915,14 Kasım).

Basiret, 24 Safer 1334 (1915, 19 Aralık).

Çelik H. (2003). 1915 Görgü Tanıklarınca Van ve Çevresinde Ermeni Olayları. Eğitim Dergisi sayı: 38, Ankara, 5.

Halaçoğlu A. XIX. Yüzyıl sonlarında Osmanlı Devleti'nde Yaşayan Ermenilerin Evlerinde Ermeni Milliyetçiliği Hakkında Ele Geçirilen Dökümanlar ve Bunun Ermeni Milliyetçiliğinin Yayılmasında Etkileri”, Hoşgörüden Yol Ayrımına Ermeniler (2009), Cilt 1. 129-152. Kayseri.

Halaçoğlu A. Ermeni Milliyetçiliği ve Ayrılıkçı Faaliyetlerinin Kökenleri (2014). Tarihte Türkler ve Ermeniler Ankara Cilt:9,159-177.

Safarov R. Batı Azerbaycan: Etno-Politik Değişiklikler ve Ermenistan'in Kurulması (1801-1921) (2002). Türkler Cilt 19, Ankara.

Safarov, R. Russkoe Zavoevanie i Demografiçeskie İzmeneniya na Kavkaze (2002) İnternational Conference "Archeology and Ethnography of the Caucasus, Baku.

Taş, N. F. Vilayat-1 Şarkıyye Islahatı ve Genel Müfettiş Nicolas Hoff (1998). Atatürk Araştırma Merkezi Dergisi C. XIV. 42,923-968.

Yeni İkbal, 5 Şevval 1333 (1915, 4 Ağustos).

Yeni İkbal, 1 Şevval 1333 (1915, 9 Ağustos).

Yeni İkbal, 11 Şevval 1333, (1915, 10 Ağustos).

Yeni İkbal, 1 Şevval 1333 (1915, 12 Ağustos).

Yeni İkbal, 22 Ramazan 1333, (1915, 16 Ağustos).

Yeni İkbal, 26 Ramazan 1333 (1915, 20 Ağustos).

Yeni İkbal, 15 Şevval 1333 (1915, 26 Ağustos).
Yeni İkbal, 3 Zilhicce 1333 (1915, 30 Eylül).

Yeni İkbal, 16 Zilhicce 1333, (1915, 13 Ekim).

Yeni İkbal, 25 Zilhicce 1333, (1915, 22 Ekim).

Yeni İkbal, 28 Muharrem 1334, (1915, 23 Kasım).

Yeni İkbal, 12 Safer 1334, (1915, 8 Aralık).

Yeni İkbal, 22 Safer 1334 (1915, 17 Aralık).

\section{Kitaplar}

Akçam, T. (2005). Ermeni Meselesi Hallolunmuştur, İstanbul: İletişim.

Armaoğlu, F. (1999). 19. Yüzyıl Siyasi Tarihi 1789-1914, Ankara: TTK.

Arif, M. (2005). Başımıza Gelenler: Cilt 2. Neşrden M. Ertuğrul Düzdağ, İstanbul: Babıali Kültür.

Ata, F. (2005). İşgal İstanbul'unda Tehcir Yargılamaları, Ankara: TTK.

Bayur, Y. H. (1983). Türk İnkılabı Tarihi: Cilt 3, kısım 3. Ankara: TTK.

Bolat, G. (2009). Ermeni Meselesinin Ortaya Çıkışında İran’in Rolü ve İran-Ermeni İlişkileri: Cilt 2. Hoşgörüden Yol Ayrımına Ermeniler, Kayseri.

DAGM, (2011). Azerbaycan Belgelerinde Ermeni Sorunu, Ankara.

Gürün, K. (2012). Ermeni Dosyası, Bilgi Yayınevi, İstanbul: Remzi.

Halaçoğlu, Y. (2008). Sürgünden Soykırıma Ermeni İddiaları, İstanbul: Babıali Kültür.

Kaçaznuni, O. (2005). Taşnak Partisinnin Yapacă̆ı Bir Şey Yok, Arif Acaloğlu (Çev.) İstanbul: Kaynak.

Maleville, G. (2003). 1915 Osmanl- Rus Ermeni Trajedisi, Fransız Avukatın Ermeni Tezleri Karşısında Türkiye Savunması, Nejdet Bakkaloğlu (Çev.) İstanbul: Toplumsal Dönüşüm. 
Özkan, S. H. (2014). Osmanl Devletinden İran'a Ermeni Göçü ve Sonuçları: Cilt 7. Tarihte Türkler ve Ermeniler, Ankara: TTK.

Sarıahmetoğlu, N. (2006). Azeri-Ermeni İlişkileri (1905-1920), Ankara: TTK.

Uras, E. (1976). Tarihte Ermeniler ve Ermeni Meselesi, Belge Yayınları, İstanbul: Belge.

\section{İnternet}

Çelik, Hüseyin, 1915 Görgü Tanıklarınca Van ve Çevresinde Ermeni Olayları, http://www.Ermenisorunu.gen.tr/turkce/makaleler/makale34.html, erişim tarihi 10.12.2013.

\section{Ansiklopediler}

ACE Azerbaycan Sovyet Ansiklopedisi (1976) (Cilt. 1, s. 503). Bakü.

ACE Azerbaycan Sovyet Ansiklopedisi (1978) (Cilt. 2, s. 150). Bakü.

ACE Azerbaycan Sovyet Ansiklopedisi (1981) (Cilt. 5, s. 113). Bakü.

\section{Tezler}

Mustafayev, B. (2009). Ermenilerin Kuzey Azerbaycan'daki Faaliyetleri (1905-1920), (Basılmamış Doktora Tezi), Ege Üniversitesi Türk Dünyası Araştırmaları Enstitüsü, Türk Tarihi Ana Bilim Dalı, İzmir.

\section{Ekler}

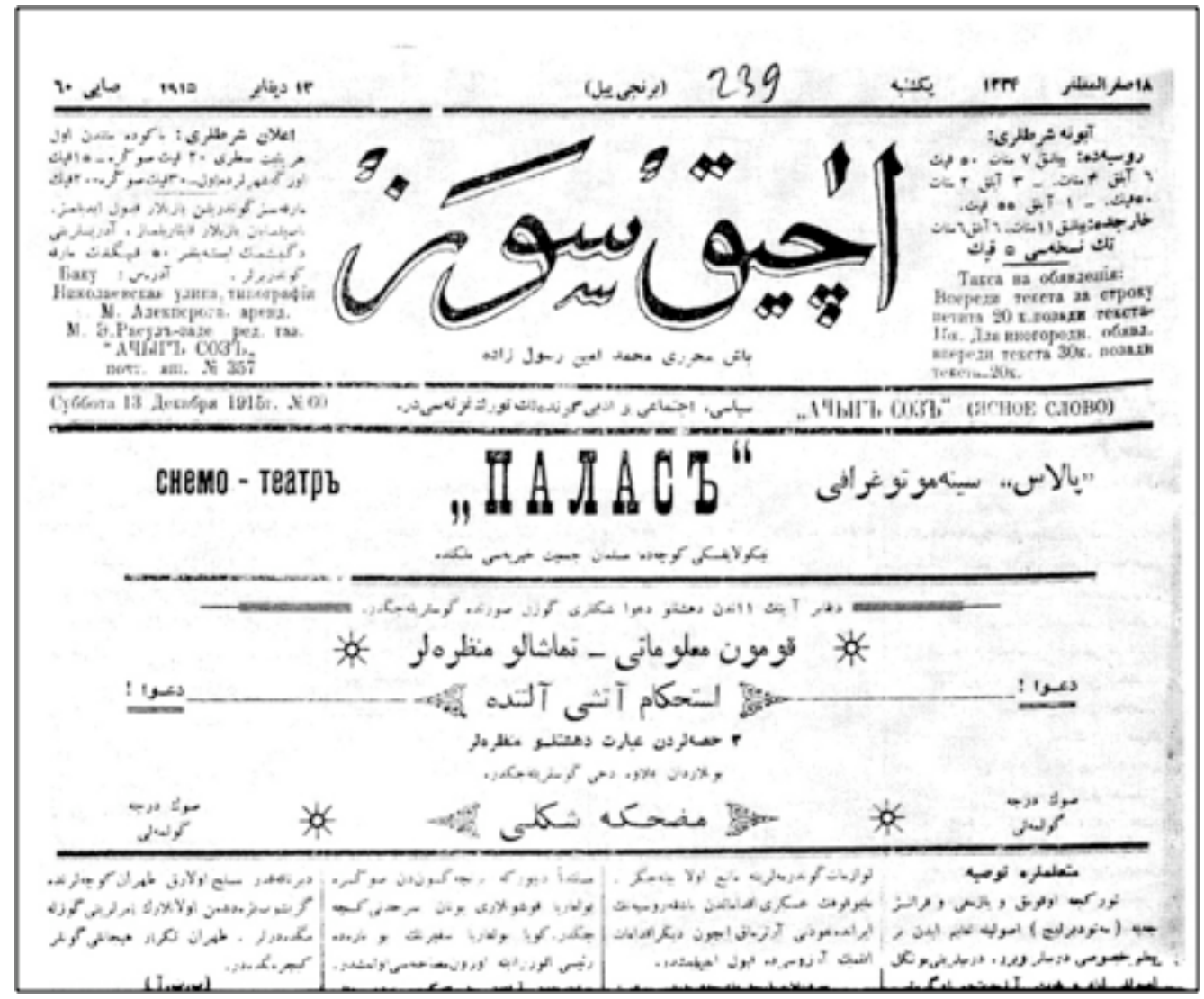

Şekil1. 13 Aralık 1915 tarihli Açık Söz Gazetesi 

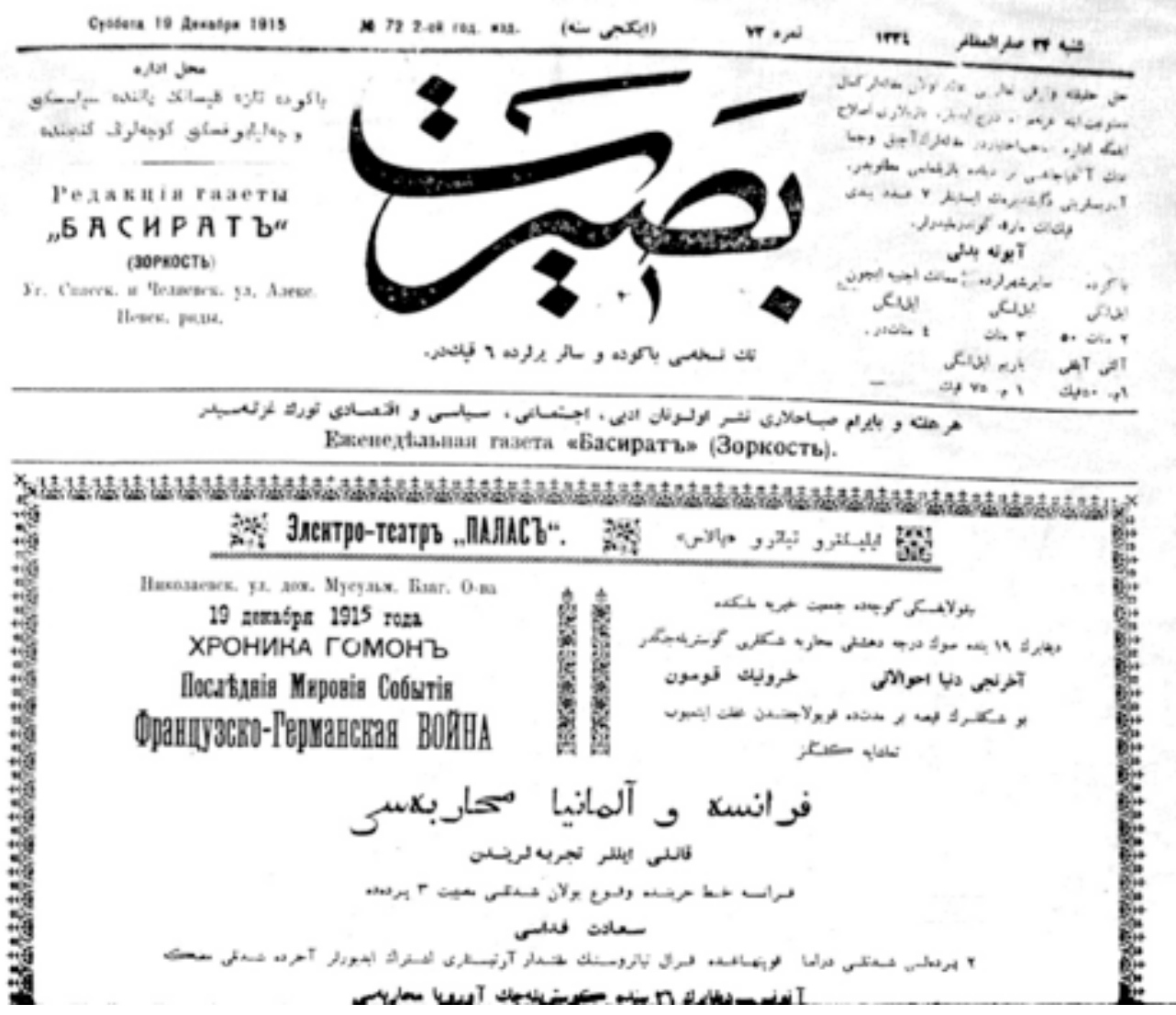

Şekil 2.19 Aralık Tarihli Basiret Gazetesi 


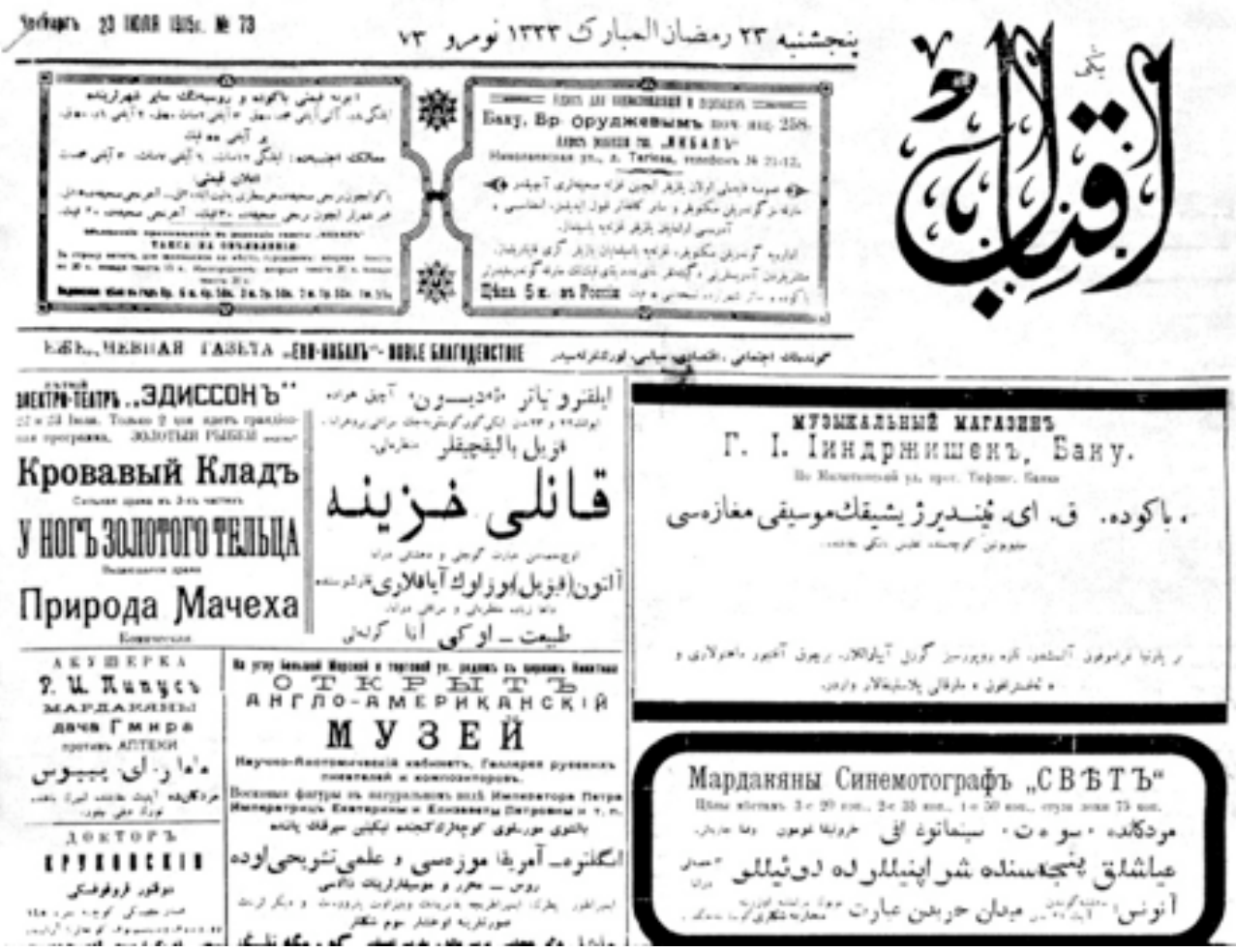

Şekil 3.23 Temmuz 1915 Tarihli Yeni Ikbal Gazetesi 


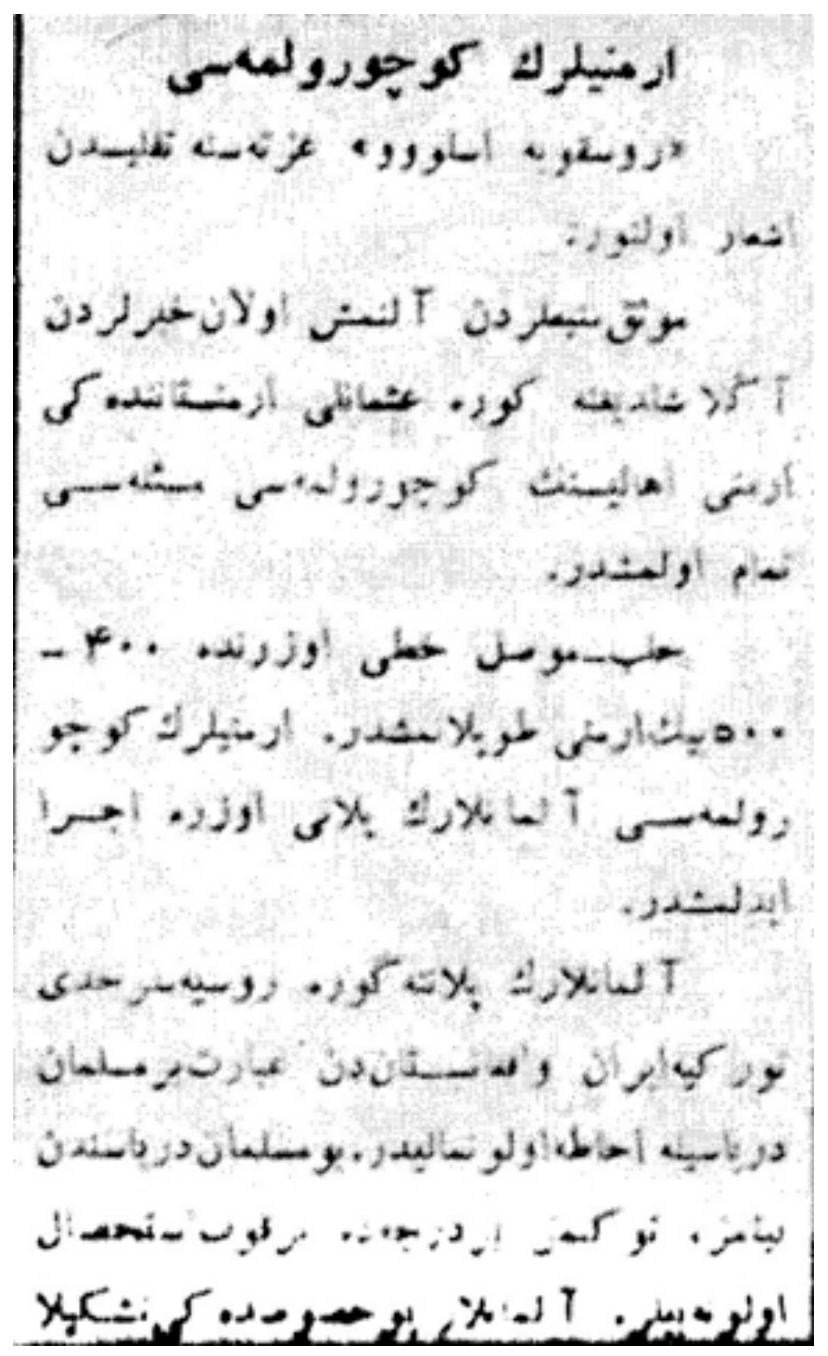

Şekil 4. Açık Söz Gazetesinin 3 Aralık 1915 Tarihli “Ermenilerin Köçürülmesi" Başlıklı Haberi 